\title{
EFEKTIVITAS PUPUK ORGANIK CAIR PAITAN, BABANDOTAN DAN ECENG GONDOK PADA TANAMAN BAWANG MERAH
}

\section{The Effectiveness of Liquid Organic Fertilizer of Mexican sunflower, Billygoat weed and Water hyacinth on Shallot}

\author{
Ayu Selpiya ${ }^{1}$, Nanik Setyowati ${ }^{* *}$ dan Fahrurrozi ${ }^{2}$ \\ ${ }^{1}$ Program Studi Agroekoteknologi, Fakultas Pertanian, Universitas Bengkulu \\ ${ }^{2}$ Jurusan Budidaya Pertanian, Fakultas Pertanian, Universitas Bengkulu \\ Beringin Raya, Muara Bangka Hulu, Kota Bengkulu, Bengkulu 38119
}

Alamat korespondensi: nsetyowati@unib.ac.id

\begin{abstract}
ABSTRAK
Keunggulan Pupuk Organik Cair (POC) dibandingkan pupuk sintetik adalah memiliki efek residu yang lebih kecil bagi lingkungan. Disamping itu, selain kontribusinya dalam menyediakan unsur hara, POC dapat dibuat dari berbagai sumber bahan organik. Gulma atau tanaman pengganggu yang keberadaannya tidak diinginkan dapat dimanfaatkan sebagai sumber POC. Penelitian ini bertujuan untuk menentukan kosentrasi dan jenis POC terbaik terhadap pertumbuhan dan hasil tanaman bawang merah. Penelitian dilaksanakan di Kebun Percobaan Fakultas Pertanian, Universitas Bengkulu. Rancangan yang digunakan adalah Rancangan Acak Lengkap pola faktorial yang terdiri atas dua faktor perlakuan dan diulang tiga kali. Faktor pertama adalah Jenis POC, yaitu POC yang berasal dari gulma paitan (Tithonia diversifolia), babandotan (Ageratum conyzoides) dan eceng gondok (Eichhornia crassipes) sedangkan faktor kedua adalah konsentrasi POC terdiri atas $0 \%, 25 \%, 50 \%, 75 \%$ dan $100 \%$. Variabel yang diamati meliputi tinggi tanaman, jumlah daun per rumpun, tingkat kehijauan daun, bobot brangkasan kering bagian atas, jumlah umbi per tanaman, dan bobot segar umbi per tanaman. POC berbahan dasar gulma paitan, gulma babandotan, dan eceng gondok memiliki dampak yang sama terhadap pertumbuhan dan hasil tanaman bawang merah. Oleh karena itu, ketiga gulma tersebut memiliki potensi sebagai POC untuk diaplikasikan pada tanaman bawang merah.
\end{abstract}

Kata kunci: babandotan, bawang merah, eceng gondok, gulma paitan, POC.

\begin{abstract}
Liquid Organic Fertilizer (LOF) application has less negative environmental effect compared to that of synthetic fertilizer. The advantage of LOF besides the contribution to nutrient content, varies sources of organic material also available for $L O F$. Weeds, known as unwanted plants, have potential as sources of $L O F$. The purpose of this study was to determine the weed based LOF for growth and yield of shallots, weed-based LOF concentration for growth and yield of shallots and determine the best combination of weeds and LOF concentration for growth and yield of shallots. The study was conducted in the Experimental Site of the Faculty of Agriculture, University of Bengkulu, using a Completely Randomized Design with two factors. The first factor was weed-based LOF consisting of 3 weed species, namely mexican sunflower (Tithonia diversifolia), billygoat weed (Ageratum conyzoides), and water hyacinth (Eichhornia crassipes). The second factor was the POC concentration, consists of 5 levels, namely $0 \%, 25 \%, 50 \%, 75 \%$, and $100 \%$. Observed variables were plant height, number of leaf hill ${ }^{-1}$, greenness level, shoot dry weight, number of bulbs hill ${ }^{-1}$, and weight of fresh bulbs hill ${ }^{-1}$. The results showed that LOF of mexican sunflower, billygoat weed, and Water hyacinth had an equal impact on the growth and yield of shallots.
\end{abstract}

Keywords: billygoat weed, LOF, mexican sunflower, shallot, water hyacinth.

\section{PENDAHULUAN}

Salah satu upaya yang dilakukan untuk meningkatkan produktivitas bawang merah adalah melalui pemupukan baik melalui pupuk anorganik maupun pupuk organik. Pupuk anorganik merupakan pupuk yang berasal dari bahan-bahan kimia sintetik yang peranannya dapat membantu meningkatkan hara pada tanah serta memenuhi kebutuhan tanaman. Pupuk 
organik merupakan pupuk yang berasal dari bahan-bahan organik seperti dari tanaman, limbah, serbuk gergaji, hewan atau pupuk kandang (Hartatik dan Widowati, 2015). Berbagai jenis pupuk kandang yang sering digunakan antara lain pupuk kandang ayam, sapi, dan kambing. Salah satu pupuk kandang yang mengandung hara cukup tinggi adalah pupuk kandang sapi. Pupuk kandang sapi mengandung 2,45\% N; 1,5\% P; 2,0\% K; 4,0\% Ca; 1,0\% Mg; dan 0,5\% S (Sinartani, 2013).

Pupuk kandang sapi berpengaruh terhadap pertumbuhan dan hasil tanaman terong (Evanita et al., 2014). Pupuk kandang sapi pada dosis 20 ton ha ${ }^{-1}$ atau $8 \mathrm{~g}$ polibag $^{-1}$ juga berpengaruh terhadap jumlah cabang produktif, jumlah buah dan bobot buah tanaman cabai (Hafizah dan Mukarramah, 2017). Hasil penelitian lain juga menunjukkan pupuk kandang sapi pada dosis 15 ton/ha berpengaruh terhadap jumlah tunas, panjang umbi dan bobot umbi tanaman ubi jalar (Neltriana, 2015). Disamping pupuk kandang sapi, penelitian lain menunjukkan pupuk kandang ayam juga berpengaruh positif terhadap tanaman cabai (Prasetyo, 2014), kubis (Jarangga et al. 2018) dan tomat (Yulianingsih, 2018), sedangkan pupuk kandang kambing berpengaruh terhadap tanaman sawi hijau (Anjarwati et al, 2017) dan tomat (Hasifah et al, 2017). Pupuk organik dapat diaplikasikan baik dalam bentuk padat maupun cair.

Pupuk organik cair (POC) mudah diserap oleh tanaman karena selain dapat diaplikasikan ke tanah POC juga dapat diaplikasikan secara langsung melalui daun. Hasil penelitian yang dilakukan Azzyanti et al. (2016) menunjukkan, aplikasi POC berpengaruh terhadap jumlah daun bawang merah, sedangkan interval waktu aplikasi berpengaruh terhadap tinggi tanaman, diameter umbi dan bobot kering jual umbi.

Gulma (tumbuhan pengganggu) seperti gulma paitan (Tithonia diversivolia), babandotan (Ageratum conyzodies) dan eceng gondok (Eichornia crassipes) memiliki potensi besar sebagai bahan dasar pembuatan POC (Fahrurrozi et al., 2015; Fahrurrozi et al., 2020). Paitan merupakan jenis gulma berdaun lebar yang mengandung unsur hara makro $\mathrm{N}$ total cukup tinggi yaitu 6,55\% (Fahrurrozi et al. 2017). Hasil penelitian Hutomo et al. (2015) menunjukkan, pupuk hijauan paitan dapat meningkatkan pertumbuhan dan hasil tanaman jagung dan pada dosis 10 ton $\mathrm{ha}^{-1}$ mampu menghasilkan jagung sebesar 9,2 ton $\mathrm{ha}^{-1}$. Kompos paitan juga berpengaruh positif terhadap pertumbuhan dan produksi tanaman tomat (Sari et al. 2017), kol bunga (Simatupang, 2014) dan kedelai (Glycine max) (Lestari, 2016).

Babandotan merupakan gulma berdaun lebar yang berasal dari suku 
Asteraceae. Babandotan mengandung $\mathrm{N}$ total $6,55 \%$; P 1,71\%; dan K 8.59 mg/100 mg (Fahrurrozi et al. 2017). Hasil penelitian Anhar et al. (2018) menunjukkan, bokhasi babandotan $120 \mathrm{~g}$ polybag $^{-1}$ berpengaruh positif terhadap bobot tomat. Tidak hanya gulma darat, gulma air juga dapat dimanfaatkan sebagai sumber pupuk organik. Eceng gondok yang merupakan gulma air berdaun lebar memiliki kandungan hara N 4,17\%; P 0,32\%; dan $\mathrm{K}$ $4,07 \mathrm{mg} / 100 \mathrm{~g}$ (Fahrurozi et al. 2017). Moi et al. (2015) melaporkan, pemberian POC eceng gondok dapat meningkatkan tinggi tanaman, jumlah daun, bobot segar dan bobot kering tanaman sawi.

Salah satu aspek yang mempengaruhi efektivitas penggunaan POC untuk meningkatkan pertumbuhan dan hasil tanaman adalah kosentrasi pupuk yang digunakan. Hasil penelitian Nugrahini (2013) menunjukkan, POC Nasa dengan kosentrasi $3 \mathrm{ml} \mathrm{L}^{-1}$ berpengaruh terhadap tinggi tanaman, jumlah daun, jumlah anakan, bobot umbi dan produksi umbi bawang merah. POC paitan pada kosentrasi $8 \mathrm{ml} /$ tanaman/aplikasi pengaruhnya terhadap tanaman kailan (Brassica oleraceae L.) lebih baik dibandingkan konsentrasi lainnya $(4,8,12,7,14$ dan 21 $\mathrm{ml} /$ tanaman/aplikasi) (Sinaga et al., 2014) sedangkan tanaman seledri hasilnya lebih baik jika dipupuk dengan POC eceng gondok pada konsentrasi $300 \mathrm{ml}$ dibandingkan perlakuan $\mathrm{P}_{0}$ (kontrol), $\mathrm{P}_{1}$ (100ml), $\mathrm{P}_{2}$ (150ml), $\mathrm{P}_{3}$ (200ml), maupun $\mathrm{P}_{4}(250 \mathrm{ml})$. Penelitian ini bertujuan untuk menentukan jenis gulma sebagai bahan dasar pembuatan POC yang terbaik bagi pertumbuhan dan hasil bawang merah dan menentukan kosentrasi POC berbahan dasar gulma terbaik bagi pertumbuhan dan hasil bawang merah pada ultisol.

\section{METODE PENELITIAN}

Penelitian dilaksanakan di Kebun Percobaan Fakultas Pertanian, Universitas Bengkulu pada ketinggian $16 \mathrm{~m}$ dpl. dengan menggunakan Rancangan Acak Lengkap (RAL) pola faktorial dan dua faktor. Faktor pertama adalah jenis POC $(\mathrm{J})$ yang terdiri dari 4 taraf perlakuan yaitu $\mathrm{J}_{1}$ (POC gulma Paitan), $\mathrm{J}_{2}$ (POC gulma Babandotan), dan $\mathrm{J}_{3}$ (POC gulma Eceng gondok). Faktor kedua adalah kosentrasi POC $(\mathrm{K})$ yang terdiri dari 5 taraf yaitu: $\mathrm{K}_{0}$ (POC 0\%), K 1 (POC 25\%), $\mathrm{K}_{2}(\mathrm{POC} 50 \%), \mathrm{K}_{3}$ (POC 75\%), dan $\mathrm{K}_{4}$ (POC $100 \%$ ). Dari kedua perlakuan yang digunakan diperoleh 15 kombinasi perlakuan dan setiap kombinasi perlakuan diulang 5 kali

Penelitian dimulai dengan pembuatan pupuk organik cair. Pembuatan pupuk organik cair (POC) dilakukan melalui proses sebagaimana yang dilakukan oleh Fahrurrozi et al. (2015) dengan beberapa modifikasi. Media tanam yang digunakan adalah tanah Ultisol yang telah 
dikeringanginkan terlebih dahulu selama 3 hari. Setelah kering angin selanjutnya diayak dan ukuran polibag yang digunakan untuk penanaman adalah $7,5 \mathrm{~cm}$ x $20 \mathrm{~cm}(1 \mathrm{x}$ t). Setiap polibag diisi $2 \mathrm{~kg}$ tanah dan polibag disusun dengan jarak tanam antar polibag $20 \mathrm{~cm}$ (dalam baris) dan $50 \mathrm{~cm}$ (antar baris). Pupuk kandang sapi digunakan sebagai pupuk dasar pada dosis 15 ton/ha dan diaplikasikan 3 hari sebelum tanaman (Sumarni dan Hidayat, 2005). Pupuk anorganik yang digunakan sesuai dosis rekomendasi yaitu urea $240 \mathrm{~kg} / \mathrm{ha}$, KCl $200 \mathrm{~kg} / \mathrm{ha}$ dan pupuk SP-36 $300 \mathrm{~kg} / \mathrm{ha}$ (Rahayu et al., 2016).

Benih bawang varietas Batu Ijo ditanam setelah sebelumnya dipotong sekitar 1/3 bagian atasnya (Setiawan et al., 2015). Aplikasi POC dilakukan dengan cara menyiramkan ke media tanam dengan total volume 1 (satu) liter per tanaman selama masa pertumbuhannya dengan konsentrasi masing-masing sesuai dengan perlakuan. POC diaplikasikan melalui tanah dengan cara disiramkan pada minggu ke 2, 3, 4, dan 5 setelah tanam sebanyak $200 \mathrm{~mL}$ pada minggu ke 2 dan 3 dan $300 \mathrm{~mL}$ pada minggu ke 4 dan 5.

Penyulaman dilakukan 1 minggu setelah tanam (MST), pengairan sekali sehari untuk menjaga kelembaban tanah sedangkan penyiangan secara mekanis dilakukan 2 MST. Panen bawang merah dilakukan ketika tanaman telah menunjukkan ciri-ciri fisik seperti pangkal daun telah lemas, daun berwarna kuning, umbi telah muncul ke permukaan tanah dan umbi berwarna merah keunguan.

Pengamatan dilakukan terhadap variabel tinggi tanaman, jumlah daun per rumpun, tingkat kehijauan daun, bobot brangkasan kering bagian atas, jumlah umbi per tanaman dan bobot segar umbi per tanaman. Selanjutnya data yang diperoleh dianalisis secara statistik dengan menggunakan Analisis Ragam (uji F) $p=5 \%$. Hasil yang berbeda nyata diuji lanjut dengan Uji Beda Nyata Terkecil (BNT).

\section{HASIL DAN PEMBAHASAN}

\section{Gambaran Umum Penelitian}

Saat penelitian berlangsung curah hujan rata-rata $30,80 \mathrm{~mm} / \mathrm{bln}$, suhu rata-rata $26.92^{\circ} \mathrm{C}$, kelembaban rata-rata $84.38 \%$ dan $\mathrm{pH}$ tanah 4.2 sedangkan syarat tumbuh tanaman bawang merah adalah suhu udara $25-32^{0} \mathrm{C}$, kelembaban udara 50-70\%, pH tanah 5.6-6.5 dengan iklim 0-5 bulan basah dan 4-6 bulan kering (Pusat Penelitian dan Pengembangan Hortikultura, 2019). Dengan demikian pada saat penelitian berlangsung, kondisi lingkungan seperti kelembaban dan curah hujannya lebih tinggi dari syarat tumbuh tanaman dengan $\mathrm{pH}$ tanah yang lebih rendah. Kondisi ini berpengaruh terhadap pertumbuhan dan hasil tanaman bawang merah. 
Hasil penelitian menunjukkan, kosentrasi POC hanya berpengaruh terhadap tinggi tanaman pada 3 - 7 MST dan bobot kering daun sedangkan jenis POC hanya berpengaruh terhadap tinggi tanaman pada 6 dan 7 MST dan pada tingkat kehijauan daun. Tidak terdapat interaksi antara konsentrasi dan jenis POC.

Pengaruh Konsentrasi POC terhadap Pertumbuhan dan Hasil Tanaman

Penggunaan POC pada berbagai konsentrasi berpengaruh terhadap tinggi tanaman setelah umur tanaman melewati 2 minggu setelah tanam (Tabel 1).

Selama masa pertumbuhan vegetatif, tanaman bawang merah membutuhkan hara yang cukup untuk memenuhi kebutuhan tanaman. Tinggi tanaman bawang merah meningkat setiap minggunya. Meski demikian, tanaman kontrol pada minggu ke 3 sampai ke 7 tanamannya lebih tinggi dibandingkan dengan tanaman yang dipupuk dengan POC pada konsetrasi 75\% maupun 100\% (Tabel 1). Diduga konsentrasi POC $75 \%$ dan $100 \%$ terlalu tinggi sehingga menyebabkan ujung daun tanaman bawang merah menguning. Purba (2011) menyatakan, pemberian POC dan kosentrasi POC harus sesuai dengan kebutuhan tanaman, tidak terlalu rendah ataupun terlalu pekat. Jika kosentrasi POC yang digunakan melebihi yang dianjurkan maka tidak akan mendapatkan hasil yang sesuai. Disamping tinggi tanaman, perbedaan konsentrasi POC yang diberikan juga tidak berpengaruh terhadap jumlah daun tanaman bawang merah (Tabel 2).

Sebagaimana tinggi tanaman, jumlah daun tanaman bawang merah juga mengalami peningkatan setiap minggunya. Jumlah daun bawang merah berkisar antara 21 sampai 26 helai (Tabel 2). Selama pertumbuhan tanaman, jumlah daun bawang merah tidak dipengaruhi oleh konsentrasi POC yang diberikan. Daun memiliki peran besar dalam proses fotosintesis dan kegiatan fotosintesis ini sangat bergantung pada nutrisi yang tersedia. Latifa (2015) menyatakan, daun merupakan salah satu organ tumbuhan yang

Tabel 1. Pengaruh konsetrasi POC terhadap tinggi tanaman bawang merah pada berbagai waktu pengamatan

\begin{tabular}{lccccccc}
\hline \multirow{2}{*}{ Kosentrasi } & \multicolumn{7}{c}{ Waktu Pengamatan (MST) } \\
\cline { 2 - 8 } & 1 & 2 & 3 & 4 & 5 & 6 & 7 \\
\hline Kontrol & $6,46 \mathrm{a}$ & $18,08 \mathrm{a}$ & $25,43 \mathrm{a}$ & $27,90 \mathrm{a}$ & $28,46 \mathrm{a}$ & $28,46 \mathrm{a}$ & $28,46 \mathrm{a}$ \\
$25 \%$ & $4,03 \mathrm{a}$ & $16,61 \mathrm{a}$ & $20,66 \mathrm{~b}$ & $24,23 \mathrm{ab}$ & $25,30 \mathrm{ab}$ & $26,10 \mathrm{a}$ & $26,10 \mathrm{a}$ \\
$50 \%$ & $4,92 \mathrm{a}$ & $17,64 \mathrm{a}$ & $21,61 \mathrm{~b}$ & $24,03 \mathrm{ab}$ & $24,86 \mathrm{~b}$ & $26,13 \mathrm{a}$ & $26,13 \mathrm{a}$ \\
$75 \%$ & $5,92 \mathrm{a}$ & $17,50 \mathrm{a}$ & $19,40 \mathrm{~b}$ & $21,03 \mathrm{~b}$ & $22,50 \mathrm{~b}$ & $22,50 \mathrm{~b}$ & $22,50 \mathrm{~b}$ \\
$100 \%$ & $2,94 \mathrm{a}$ & $15,49 \mathrm{a}$ & $18,66 \mathrm{~b}$ & $20,80 \mathrm{~b}$ & $21,93 \mathrm{~b}$ & $22,33 \mathrm{~b}$ & $22,33 \mathrm{~b}$ \\
\hline
\end{tabular}

Keterangan: angka-angka yang diikuti oleh huruf yang sama pada kolom yang sama tidak berbeda nyata menurut uji BNT taraf $p=5 \%$. 
Tabel 2. Pengaruh konsentrasi POC terhadap jumlah daun bawang merah

\begin{tabular}{lccccccc}
\hline \multirow{2}{*}{ Kosentrasi } & \multicolumn{7}{c}{ Waktu Pengamatan (MST) } \\
\cline { 2 - 8 } & 1 & 2 & 3 & 4 & 5 & 6 & 7 \\
\hline Kontrol & $4,00 \mathrm{a}$ & $11,46 \mathrm{a}$ & $16,86 \mathrm{a}$ & $20,26 \mathrm{a}$ & $20,66 \mathrm{a}$ & $20,66 \mathrm{a}$ & $20,66 \mathrm{a}$ \\
$25 \%$ & $2,73 \mathrm{a}$ & $12,46 \mathrm{a}$ & $15,86 \mathrm{a}$ & $20,73 \mathrm{a}$ & $25,53 \mathrm{a}$ & $27,13 \mathrm{a}$ & $26,46 \mathrm{a}$ \\
$50 \%$ & $3,46 \mathrm{a}$ & $11,40 \mathrm{a}$ & $14,13 \mathrm{a}$ & $16,80 \mathrm{a}$ & $21,06 \mathrm{a}$ & $21,80 \mathrm{a}$ & $22,00 \mathrm{a}$ \\
$75 \%$ & $3,80 \mathrm{a}$ & $12,66 \mathrm{a}$ & $16,06 \mathrm{a}$ & $18,20 \mathrm{a}$ & $20,93 \mathrm{a}$ & $22,33 \mathrm{a}$ & $23,66 \mathrm{a}$ \\
$100 \%$ & $2,20 \mathrm{a}$ & $11,66 \mathrm{a}$ & $14,66 \mathrm{a}$ & $16,40 \mathrm{a}$ & $19,06 \mathrm{a}$ & $19,26 \mathrm{a}$ & $22,33 \mathrm{a}$ \\
\hline
\end{tabular}

Keterangan: angka-angka yang diikuti oleh huruf yang sama pada kolom yang sama tidak berbeda nyata menurut uji BNT taraf $p=5 \%$.

Tabel 3. Pengaruh kosentrasi POC terhadap tingkat kehijauan daun (TKD), bobot kering daun (BK daun), jumlah umbi dan bobot segar umbi (BS Umbi) tanaman bawang merah

\begin{tabular}{lcccc}
\hline \multicolumn{1}{c}{ Kosentrasi } & TKD & BK daun $(\mathrm{g} / \tan )$ & Jumlah Umbi & BS Umbi $(\mathrm{g} / \tan )$ \\
\hline Kontrol & $51,78 \mathrm{a}$ & $2,74 \mathrm{c}$ & $6,26 \mathrm{a}$ & $16,68 \mathrm{a}$ \\
$25 \%$ & $53,26 \mathrm{a}$ & $3,08 \mathrm{~b}$ & $7,93 \mathrm{a}$ & $18,87 \mathrm{a}$ \\
$50 \%$ & $56,02 \mathrm{a}$ & $3,25 \mathrm{ab}$ & $6,93 \mathrm{a}$ & $16,95 \mathrm{a}$ \\
$75 \%$ & $53,59 \mathrm{a}$ & $3,34 \mathrm{a}$ & $8,80 \mathrm{a}$ & $16,98 \mathrm{a}$ \\
$100 \%)$ & $56,20 \mathrm{a}$ & $3,32 \mathrm{ab}$ & $6,93 \mathrm{a}$ & $15,30 \mathrm{a}$ \\
\hline
\end{tabular}

Keterangan: angka-angka yang diikuti oleh huruf yang sama pada kolom yang sama tidak berbeda nyata pada uji BNT taraf $p=5 \%$.

mengandung klorofil dan berfungsi untuk menangkap sinar matahari melalui proses fotosintesis. Selain itu daun merupakan organ yang sangat penting bagi tumbuhan untuk proses kelangsungan hidupnya, karena tumbuhan merupakan tanaman yang memasok kebutuhan energinya sendiri melalui proses fotosintesis.

Jumlah daun yang tidak dipengaruhi oleh POC yang diberikan ini diduga karena ketersediaan POC bagi tanaman memerlukan waktu dan tidak langsung tersedia bagi tanaman. Media yang digunakan adalah Ultisol yang termasuk asam serta kandungan unsur haranya rendah. Hasil penelitian lain juga menunjukkan, pemberian pupuk organik cair reaksinya kurang cepat terhadap pertumbuhan vegetatif tanaman sehingga tidak mempengaruhi tinggi dan jumlah daun (Syofia et al, 2014). Tanaman membutuhkan unsur hara yang cukup untuk pertumbuhan dan perkembangan tanaman dan dalam kosentrasi yang optimun, serta didukung oleh kondisi lingkungan yang tepat (Walid dan Susylowati, 2016). Dengan demikian, pemberian POC dan kosentrasi POC yang diberikan harus sesuai dengan kebutuhan tanaman. Penggunaan POC pada berbagai konsentrasi juga tidak berpengaruh terhadap tingkat kehijauan daun (Tabel 1). Rata-rata tingkat kehijauan daun antara 51,78-56,20 (Tabel 3).

Tingkat kehijauan daun merupakan indikator banyaknya jumlah klorofil yang terkadung pada daun yang digunakan untuk 
proses fotosintesis. Unsur hara mikro magnesium yang merupakan penyusun klorofil sangat penting dalam proses fotosintesis (Syofia et al, 2014). Untuk meningkatkan pembentukkan klorofil daun dan bintil akar, tanaman membutuhkan unsur hara makro dan mikro yang cukup sehingga kemampuan fotosintesis akan meningkat (Insani, 2017). Jika fotosintesis berjalan dengan baik maka makanan yang disediakan oleh tanaman tersebut akan memenuhi pertumbuhan tanaman. Pemberian POC dengan kandungan unsur hara yang lengkap dan cukup akan memacu proses fotosintesis. Hasilnya berupa karbohidrat yang akan ditranslokasikan ke seluruh bagian tanaman (Setiyowati et al., 2010). Meski demikian beberapa hasil penelitian tentang POC memberikan respon yang bervariasi terhadap tanaman uji.

Hasil penelitian ini menunjukkan, tingkat kehijauan daun tanaman bawang merah tidak dipengaruhi oleh POC pada berbagai konsentrasi yang diberikan. Peran POC pada tanaman ditentukan oleh banyak faktor antara lain $\mathrm{pH}$ tanah. Efektivitas penyerapan unsur hara kurang optimal pada tanah dengan $\mathrm{pH}$ rendah seperti Ultisol.Sejalan dengan hasil penelitian ini, hasil penelitian Utami (2018) juga menunjukkan, pemberian berbagai kosentrasi POC $(0 \%, 25 \%, 100 \%)$ tidak berpengaruh terhadap tingkat kehijauan daun tanaman jeruk gerga. Meskipun tingkat kehijauan daun tidak dipengaruhi oleh POC namun berpengaruh terhadap bobot kering daun (Tabel 3). Dalam penelitian ini hasilnya menunjukkan, konsentrasi POC 75\% menghasilkan bobot kering daun yang lebih tinggi dibandingkan konsentrasi 25\% maupun tanaman kontrol. Rata-rata bobot kering daun bawang merah per rumpun antara 2,74 g - 3,34 g (Tabel 3).

Secara umum hasil penelitian ini menunjukkan, tinggi tanaman bawang merah yang diberi POC tidak lebih baik dibandingkan tanaman kontrol namun menghasilkan bobot kering daun yang lebih baik dibandingkan kontrol (Tabel 3). Ratarata jumlah daun tanaman yang dipupuk dengan POC adalah $22.0 \quad-25.5$ helai/tanaman sedangkan pada kontrol sebanyak 20.7 helai. Jumlah daun berpengatuh terhadap bobot kering daun karena berkaitan dengan proses fotosintesis tanaman. Tanaman dengan jumlah daun lebih banyak, maka kegiatan fotosintesisnya lebih besar dibandingkan yang jumlah daunnya lebih sedikit. Pada akhirnya akan menghasilkan fotosintat yang lebih tinggi yang dicerminkan dari bobot kering brangkasanya.

Kartika et al. (2015) melaporkan, dengan bertambahnya jumlah daun, maka cahaya yang diserap oleh tanaman akan meningkatkan proses fotosintesis dan fotosintatnya ditranslokasikan untuk pertumbuhan bagian-bagian tanaman 
seperti pada akar, batang dan daun. Semakin banyak daun pada tanaman maka semakin tinggi bobot kering daun. Jumlah daun yang terbentuk mempengaruhi bobot umbi dan juga jumlah umbi (Widiastutik et al., 2018).

Pemberian POC pada berbagai konsentrasi tidak berpengaruh terhadap jumlah umbi maupun bobot segar umbi. Jumlah umbi bawang merah yang dihasilkan berkisar antara $6.26-8.80$ dengan bobot segar umbi berkisar antara 15.30 - $18.87 \mathrm{~g} / \operatorname{tanaman}$ (Tabel 3). Umbi merupakan tempat menyimpannya hasil cadangan proses fotosintesis. Salah satu hasil proses fotosintesis adalah fruktan dan fruktan sangat diperlukan untuk pembentukan umbi (Yetti dan Elita, 2008). Tanaman bawang merah yang mampu menghasilkan bobot umbi yang tinggi karena karbohidrat, protein, lemak dan asam-asam organik lainnya yang dihasilkan dari kegiatan fotosintesis disimpan didalam umbi lapis (Jamilah dan Novita, 2016).

Hasil bawang merah dari penelitian ini lebih rendah dibandingkan potensi hasilnya. Bobot segar var Batu Ijo sekitar 92 g per rumpunnya. Hal ini antara lain disebabkan $\mathrm{pH}$ tanah yang rendah pada Ultisol yaitu 4.2 sedangkan bawang merah menghendaki $\mathrm{pH}$ antara $5.6-6.5$. Kondisi ini menyebabkan penyerapan unsur hara yang dilakukan oleh tanaman kurang optimal. Widiastutik et al, (2018) melaporkan, jumlah daun yang terbentuk mempengaruhi bobot umbi dan juga jumlah umbi. Daun merupakan tempat terjadinya proses fotosintesis yang mana apabila proses fotosintesis berjalan baik maka perkembangan pada tamanan akan baik juga (Nurjani, 2011). Terbentuknya jumlah daun dapat mempengaruhi besar dan bobot umbi karena semakin banyak daun maka semakin besar kemampun untuk terjadinya proses fotosintesis dalam menghasilkan karbohidrat untuk ditranslokasikan ke bagian akar atau umbi (Fajrin, 2019). Pertumbuhan dan hasil tanaman dipengaruhi oleh 2 faktor yaitu faktor internal dan faktor ekternal (Putri, 2018). Faktor internal merupakan faktor yang dipengaruhi oleh sifat genetik seperti umur tanaman, morfologi tanaman, daya hasil tanaman, kapasitas menyimpan cadangan makanan, ketahanan terhadap penyakit dan lain-lainnya. Sedangkan faktor eksternal merupakan faktor lingkungan seperti iklim, tanah dan biotik.

Jika dibandingkan dengan deskripsi varietasnya, pada penelitian ini bobot segar umbi yang dihasilkan lebih rendah namun jumlah umbinya lebih banyak. Menurut deskripsi, bobot segar umbi kurang lebih 90 g per rumpun sedangkan pada penelitian ini hanya $19 \mathrm{~g}$ dan sedangkan jumlah umbinya 2-5 umbi per rumpun dan pada penelitian ini menghasilkan 6-9 umbi per rumpun. Dengan demikian umbi yang dihasilkan 
tergolong umbi yang berukuran kecil yaitu 0,98-1,26 setiap umbi (Jamilah et al., 2017).

Faktor lingkungan seperti $\mathrm{pH}$ yang rendah (4.2) dan kelembaban yang tinggi diduga menjadi penyebab rendahnya hasil bawang merah.

\section{Pengaruh Jenis POC terhadap Pertumbuhan dan Hasil Tanaman}

Jenis POC yang digunakan tidak berpengaruh terhadap tinggi tanaman bawang merah kecuali pada 6 dan 7 MST. Secara umum hasil penelitian menunjukkan, perbedaan jenis POC yang digunakan pada penelitian ini tidak berpengaruh terhadap tinggi tanaman bawang merah kecuali pada 6 dan 7 MST dimana tinggi tanaman bawang merah yang dipupuk dengan POC paitan lebih rendah dibandingkan kedua jenis pupuk lainnya (Tabel 4).

Tanaman membutuhkan hara N, P, K yang merupakan hara esensial yang berperan untuk pertumbuhan dan perkembangan tanaman (Syafrudin dan Wachid, 2015). Isnaini et al. (2014) menyatakan, macam dan kandungan unsur hara makro dan mikro pada POC berpengaruh nyata pada pertumbuhan tanaman terung. Hasil penelitian Amir dan Fauzy (2018) menunjukkan, jenis POC batang pisang berpengaruh pada tinggi tanaman dan menghasilkan pertumbuhan dan produksi kedelai lebih baik dibandingkan dengan POC sabut kelapa.

Hasil penelitian juga menunjukkan, jenis POC yang diaplikasikan tidak berpengaruh terhadap jumlah daun bawang merah (Tabel 5). Tabel 5 menunjukkan, jumlah daun bawang merah pada minggu ke tujuh antara 22-23 helai dan tidak berbeda antara tanaman yang dipupuk baik dengan POC paitan, babandotan maupun eceng gondok. Hal ini karena kandungan unsur hara dari ketiga jenis POC hampir sama. Paitan merupakan jenis gulma berdaun lebar yang mengandung unsur hara makro cukup tinggi yaitu $\mathrm{N}$ total $6,55 \%$; $\mathrm{P}$ total 0,87; dan K 3,94 mg/100g. Babandotan mengandung $\mathrm{N}$ total $6,55 \%$; P $1,71 \%$; dan $\mathrm{K} \quad 8.59 \mathrm{mg} / 100 \mathrm{mg}$ sedangkan Eceng mengandung unsur hara $\mathrm{N} 4,17 \%$; P $0,32 \%$; dan $\mathrm{K}$ 4,07 mg/100g (Fahrurozi et al. 2017).

Tabel 4. Pengaruh jenis POC terhadap tinggi tanaman bawang merah $(\mathrm{cm})$ pada berbagai waktu pengamatan

\begin{tabular}{lccccccc}
\hline \multirow{2}{*}{ Jenis POC } & \multicolumn{7}{c}{ Waktu Pengamatan (MST) } \\
\cline { 2 - 8 } & 1 & 2 & 3 & 4 & 5 & 6 & 7 \\
\hline Paitan & $5,12 \mathrm{a}$ & $16,24 \mathrm{a}$ & $19,76 \mathrm{a}$ & $21,88 \mathrm{a}$ & $23,08 \mathrm{a}$ & $23,10 \mathrm{~b}$ & $23,1 \mathrm{~b}$ \\
Babandotan & $5,67 \mathrm{a}$ & $17,97 \mathrm{a}$ & $22,38 \mathrm{a}$ & $24,30 \mathrm{a}$ & $25,38 \mathrm{a}$ & $25,54 \mathrm{a}$ & $25,54 \mathrm{a}$ \\
Eceng gondok & $3,77 \mathrm{a}$ & $16,97 \mathrm{a}$ & $21,32 \mathrm{a}$ & $24,62 \mathrm{a}$ & $25,38 \mathrm{a}$ & $25,66 \mathrm{a}$ & $25,66 \mathrm{a}$ \\
\hline
\end{tabular}

Keterangan: angka-angka yang diikuti oleh huruf yang sama pada kolom yang sama tidak berbeda nyata menurut uji BNT taraf $p=5 \%$. 
Tabel 5. Pengaruh jenis POC terhadap jumlah daun tanaman bawang merah pada berbagai waktu pengamatan

\begin{tabular}{lccccccc}
\hline \multirow{2}{*}{ Jenis POC } & \multicolumn{7}{c}{ Waktu Pengamatan (MST) } \\
\cline { 2 - 8 } & 1 & 2 & 3 & 4 & 5 & 6 & 7 \\
\hline Paitan & $3,88 \mathrm{a}$ & $12,4 \mathrm{a}$ & $16,08 \mathrm{a}$ & $19,08 \mathrm{a}$ & $21,96 \mathrm{a}$ & $22,56 \mathrm{a}$ & $23,04 \mathrm{a}$ \\
Babandotan & $3,24 \mathrm{a}$ & $11,96 \mathrm{a}$ & $15,32 \mathrm{a}$ & $18,20 \mathrm{a}$ & $20,92 \mathrm{a}$ & $21,88 \mathrm{a}$ & $22,48 \mathrm{a}$ \\
Eceng gondok & $2,60 \mathrm{a}$ & $11,44 \mathrm{a}$ & $15,16 \mathrm{a}$ & $18,16 \mathrm{a}$ & $21,48 \mathrm{a}$ & $21,88 \mathrm{a}$ & $22,76 \mathrm{a}$ \\
\hline
\end{tabular}

Keterangan: angka-angka yang diikuti oleh huruf yang sama pada kolom yang sama tidak berbeda nyata menurut uji BNT taraf $p=5 \%$.

Tabel 6. Pengaruh jenis POC terhadap tingkat kehijauan daun (TKD), bobot kering daun (BK daun), jumlah umbi, dan bobot segar umbi (BS umbi) tanaman bawang merah

\begin{tabular}{lcccc}
\hline Jenis & \multicolumn{1}{l}{ TKD } & BK daun (g/tan) & Jumlah Umbi & BS umbi (g/tan) \\
\hline Paitan & $56,03 \mathrm{a}$ & $3,18 \mathrm{a}$ & $8,08 \mathrm{a}$ & $16,47 \mathrm{a}$ \\
Babandotan & $55,29 \mathrm{a}$ & $3,08 \mathrm{a}$ & $6,76 \mathrm{a}$ & $16,55 \mathrm{a}$ \\
Eceng gondok & $51,19 \mathrm{~b}$ & $3,17 \mathrm{a}$ & $7,28 \mathrm{a}$ & $17,84 \mathrm{a}$ \\
\hline
\end{tabular}

Keterangan: angka-angka yang diikuti oleh huruf yang sama pada kolom yang sama tidak berbeda nyata menurut uji BNT taraf $p=5 \%$.

Hasil penelitian Ardiyanto dan Jazilah (2018) disisi lain menunjukkan, jenis POC yang diuji berpengaruh terhadap pertumbuhan dan hasil cabai merah dan jenis POC urin kelinci lebih baik dibadingkan dengan POC urin sapi maupun POC urin kambing. Kandungan N-total POC dari gulma lebih rendah dibandingkan dengan POC urin sapi dan kandungan unsur hara ini berpengaruh terhadap pertumbuhan tanaman.

Tanaman bawang merah yang diberi POC berbasis daun paitan dan babandotan TKD nya lebih tinggi dibandingkan eceng gondok (Tabel 6). Tingkat kehijauan daun merupakan indikator banyaknya klorofil yang terkadung pada daun yang digunakan untuk proses fotosintesis. Semakin banyak daun maka semakin tinggi proses fotosintesis terjadi. Kandungan hara pada jenis POC hijauan memiliki unsur hara makro dan mikro yang tersedia untuk klorofil untuk proses fotosintesis (Manullang et al., 2014). Demikian halnya gulma paitan, babandotan dan eceng gondok juga mengandung unsur hara makro dan mikro yang memiliki peran dalam proses fotosintesis tanaman. Hasil penelitian Amir dan Fauzy (2018) menunjukkan, jenis POC batang pisang menghasilkan pertumbuhan dan produksi lebih baik pada tanaman kedelai dibandingkan POC sabut kelapa. Kedua jenis POC tersebut mengandung unsur hara makro dan mikro yang tidak sama.

Jenis POC yang diuji tidak berpengaruh baik pada bobot kering daun, jumlah umbi maupun bobot umbi bawang merah. Bobot kering daun dipengaruhi oleh jumlah daun. Jumlah daun pada tanaman 
berkaitan erat dengan bobot kering daun. Hasil penelitian yang dilakukan menunjukkan jumlah daun bawang merah tidak dipengaruhi oleh jenis POC dan bobot kering daunnya juga tidak berbeda antar perlakuan. Bobot kering yang merupakan manifestasi dari hasil fotosintat ini pada akhirnya juga berkaitan dengan hasil tanaman. Jumlah dan bobot umbi yang dihasilkan juga tidak berbeda antar perlakuan.

Umbi merupakan tempat menyimpan hasil cadangan proses fotosintesis. POC mengandung unsur hara makro dan mikro yang dibutuhkan dalam proses fotosintesis. Jika unsur hara pada tanaman kurang maka pertumbuhan dan hasil tanaman juga kurang baik (Monika et al., 2013). Dalam hal ini, baik POC paitan, babandotan dan eceng gondok juga mengandung unsur hara makro dan mikro yang dibutuhkan tanaman (Fahrurrozi et al, 2017) namun demikian ketersediaannya bagi tanaman sangat dipengaruhi oleh banyak faktor antara lain media tanamnya.

Beberapa hasil penelitian lain yang relevan dengan hasil penelitian ini menunjukkan, jenis POC berpengaruh nyata pada jumlah cabang produktif, jumlah buah total, dan berat segar tanaman, sedangkan jenis POC yang lebih sesuai untuk pertumbuhan dan hasil tanaman tomat adalah POC CAPS dibandingkan dengan POC NASA (Putri, 2018). Hasil penelitian Jamilah et al (2017) menunjukkan, jenis POC Crocober plus mampu meningkatkan pertumbuhan dan hasil tanaman bawang merah lebih baik dibandingkan dengan jenis POC Unitas Super dan NASA. Dengan demikian respon tanaman terhadap jenis POC yang diberikan sangat tergantung dengan kandungan unsuh hara makro maupun mikro serta efektifitas penyerapannya.

\section{KESIMPULAN}

Pupuk organik cair berbahan dasar gulma pada berbagai konsentrasi yang diberikan hanya berpengaruh terhadap tinggi tanaman dan bobot kering daun bawang merah. Pupuk organik cair gulma paitan (Tithonia diversifolia), babandotan (Ageratum conyzoides) dan eceng gondok (Eichhornia crassipes) memiliki dampak yang sama terhadap pertumbuhan dan hasil tanaman bawang merah.

\section{DAFTAR PUSTAKA}

Amir, N. dan M.F. Fauzy. 2018. Pengaruh jenis pupuk organik cair limbah tanaman dan takaran pupuk kotoran ayam terhadap pertumbuhan tanaman kedelai (Glycine $\max$ L. Merril). Jurnal Klorofil, 13(1): 17-21.

Anhar, A., R. Junialdi, A. Zein, L. Advinda and I. Leilani. 2018. Growth and tomato nutrition content with bandotan (Ageratum conyzoides L.) bokashi applied. IOP Conf. Series: Materials Science and Engeenering 335. IOP Publishing. Diakses 4 Mei 2020. 
Anjarwati, H., S. Waluyo dan S. Purwanti. 2017. Pengaruh macam media dan takaran pupuk kandang kambing terhadap pertumbuhan dan hasil sawi hijau (Brassica rapa, L.). Vegetalika, 6(1): 35-45.

Ardiyanto, W. dan S. Jazilah. 2018. Pengaruh macam pupuk organik cair (POC) dan saat pemberian terhadap pertumbuhan dan produksi cabai merah (Capsicum annum L.). Jurnal Ilmiah Pertanian, 14(2): 48-56.

Azzyanti, R., Roisita dan Meirani. 2016. Respons pertumbuhan dan produksi tanaman bawang merah (Allium ascalonicum $L$.) terhadap dosis pupuk organik cair titonia (Tithonia diversifolia (Hemsl.) Gray) dan interval waktu pemberian. Jurnal Agroekoteknologi, 4(1): 2435-2446.

Evanita, E., E. Widaryanto dan Y.B.S. Henddy. 2014. Pengaruh pupuk kandang sapi pada pertumbuhan dan hasil tanaman terong (Solanum melongena L.) pada pola tanam tumpangsari dengan rumput gajah (Penisetum purpureum) tanaman pertama. Jurnal Produksi Tanaman, 2(7): 533-541.

Fahrurrozi, Z. Muktamar, N. Setyowati, S. Sudjatmiko. and M. Chozin. 2015. Evaluation of Tithonia-enriched liquid organik fertilizer for organic carrot production. Journal of Agricultural Technology, 11(8): 1705-1712.

Fahrurrozi, Y. Sariasih, Z. Muktamar, N. Setyowati, M. Chozin and S. Sudjatmiko. 2017. Identification of nutrient contents in six potential green biomasses for developing liquid organic fertilizer in closed agricultural production system. Journal on Advanced Science Enginering Information Techonologi, 7(2): 559-565.

Fahrurrozi, F., Z. Muktamar, N. Setyowati, M. Chozin and S. Sudjatmiko. 2020.
Nutrient properties of tithoniaenriched liquid organic fertilizer as affected by different types of animal feces and its effects on fresh weight of loose-leaf lettuce (Lactuva Sativa L.). International Journal on Advanced Science, Engineering, Information and Technology, 10(2): 730-735.

Fajrin, H. 2019. Pertumbuhan dan hasil tiga varietas bawang merah (Allium ascalonicum L.) terhadap kosentrasi pupuk organik cair limbah tomat di ultisol. Skripsi. Fakultas Pertanian Universitas Bengkulu, Bengkulu.

Hafizah, N. dan R. Mukarramah. 2017. Aplikasi pupuk kandang kotoran sapi pada pertumbuhan dan hasil tanaman cabai rawit (Capsicum frustescens L.) di lahan rawa lebak. Jurnal Ziraa'ah, 42(1): 1-7.

Hartatik dan Widowati. 2015. Pupuk Kandang. http://balittanah.litbang. pertanian.go.id. Diakses 3 Maret 2020.

Hasifah, A.D., T. Sumarni dan H.T. Sebayang. 2017. Pengaruh pupuk kandang kambing dan pupuk hijau (Crotalaria juncea) pada pertumbuhan dan hasil tanaman tomat (Lycopersicum esculentum, Mill.). Jurnal Produksi Tanaman, 5(12): 1972-1978.

Hutomo, P. I., Mahfudz dan S. Laude. 2015. Pengaruh pupuk hijau Tithonia diversifolia terhadap pertumbuhan dan hasil tanaman jagung (Zea mays L.). Jurnal Agrotekbis, 3(4): 475-481.

Isnaini, M., A. Rahmi dan A.P. Sujalu. 2014. Pengaruh jenis dan konsentrasi pupuk daun terhadap pertumbuhan dan hasil tanaman terung (Solanum melongena L.) varietas Mustang F1. Jurnal Agrifor, 13(1): 53-58.

Insani, N.A. 2017. Pengaruh pemberian pupuk organik cair dengan dosis yang bebeda terhadap pertumbuhan dan produktivitas jagung pakan pada lahan kering kritis. Skripsi. Fakultas 
Peternakan Universitas Hasanudin, Makasar.

Jamilah dan E. Novita. 2016. Pengaruh pupuk organik cair Crocober terhadap tanaman bawang merah (Allium ascalonicum L.). Jurnal Ipteks Terapan, 8(2): 67-73.

Jamilah, Erianto dan Fatimah. 2017. Response of red onion (Allium cepa L.) on time interval and type of liquid organic fertilizer. Jurnal Bibiet, 2(1): 27-36.

Jarangga, M.A., A. Ali dan A. Maruapey. 2018. Pengaruh jenis pupuk kandang terhadap pertumbuhan dan produksi tanaman sawi hijau (Brassica juncea L.). Media, 10(2):1-11.

Kartika, E., R. Yusuf dan A. Syakur. 2015. Pertumbuhan dan hasil tanaman tomat (Lycopersium escukentum Mill.) pada berbagai persentase naungan. Jurnal Agrotekbis, 3(6): 717-724.

Latifa, R. 2015. Karakter morfologi daun beberapa jenis pohon penghijauan hutan di kota. Prosiding Seminar Nasional Pendidikan Biologi "Peran Biologi dan Pendidikan Biologi dalam Menyiapkan Generasi Unggul dan Berdaya Saing Global" p. 6677 676.

Lestari, D. A. S. 2016. Pemanfaatan paitan (Tithonia diversifolia) sebagai pupuk organik pada tanaman kedelai. Jurnal Iptek Tanaman Pangan, 11(1): 49-56.

Manullang, S. G., A. Rahmi dan P. Astuti. 2014. Pengaruh jenis dan konsentrasi pupuk organik cair terhadap pertumbuhan dan hasil tanaman sawi (Brassica juncea L.) varietas Tosakan. Jurnal Agrifor, 13(1): 3340.

Moi, A. R., D. Pandiangan, P. Siahan dan A.M. Tangapo. 2015. Pengujian pupuk organik cair dari eceng gondok (Eichhornia crassipes) terhadap pertumbuhan tanaman sawi (Brassica juncea). Jurnal Mipa Unsrat, 4(1): 1519.

Monika, N., Novi dan L. Meriko. 2013. Pengaruh pemberian pupuk organik cair (POC) terhadap produksi tanaman sawi (Brassica juncea L.). Jurnal Geosains, 2(1): 14-17.

Neltriana, N. 2015. Pengaruh dosis pupuk kandang kotoran sapi terhadap pertumbuhan dan hasil ubi jalar (Ipomea Batatas L.). Skripsi. Fakultas Pertanian. Universitas Andalas Padang, Padang.

Nugrahini, T. 2013. Respon tanaman bawang merah (Allium ascolonicum L.) varietas Tuk Tuk terhadap pengaturan jarak tanaman dan konsentrasi pupuk organik cair nasa. Jurnal Ziraa'ah, 36(1): 60-65.

Nurjani.2011. Kajian pengendalian penyakit layu bakteri (Ralstonia Solanacearum) menggunakan agens hayati pada tanaman tomat. Jurnal Suara Perlindungan Tanaman, 1(4): $1-8$.

Prasetyo, R. 2014. Pemanfaatan berbagai sumber pupuk kandang sebagai sumber $\mathrm{N}$ dalam budidaya cabai merah (Capsicum annum L.) di tanah berpasir. Planta Tropika. Journal of Agro Science, 2(2): 125-132.

Purba, D. 2011. Pertumbuhan dan hasil padi pada empat jenis pupuk organik cair dan tiga frekuensi aplikasi. Skripsi. Fakultas Pertanian Universitas Bengkulu, Bengkulu.

Pusat Penelitian dan Pengembangan Hortikultura. 2019. Badan penelitian dan pengembangan pertanian, kementerian pertanian. www.litbang. pertanian.go.id. Diakses 3 Maret 2020.

Putri, S. Y. 2018. Pengaruh jenis dan dosis pupuk organik cair terhadap pertumbuhan dan hasil tanaman tomat (Solanum lycopersicum L.). Skripsi. 
Fakultas Pertanian Universitas Bengkulu. Bengkulu.

Rahayu, S., Elfarisna dan Rosdiana. 2016. Respon pertumbuhan dan produksi tanaman bawang merah (Allium ascalonicum L.) dengan penambahan pupuk organik cair. Jurnal Agrosains dan Teknologi, 1(1): 7-18.

Sari, W. A., A. Anhar dan A. Zein. 2017. Respon pertumbuhan dan produksi tanaman tomat (Solanum lycopersicum) dengan pemberian bokashi tithonia (Tithonia diversifolia). Jurnal Biosience, 1(1): 79-85.

Setiawan, A., R. Sipayung dan T. Simanungkalit. 2015. Pertumbuhan dan produksi bawang merah (Allium ascalonicum. L) terhadap dosis limbah cair pabrik kelapa sawit dan tipe pemotongan umbi. Jurnal Agroekoteknologi, 2(1): 340-349.

Setiyowati, S. Haryanti dan R.B. Hastuti. 2010. Pengaruh perbedaan konsentrasi pupuk organik cair terhdap produksi bawang merah (Allium ascalonicum L.). Jurnal Bioma, 12(2): 44-48.

Simatupang, P. 2014. Pengaruh dosis kompos paitan (Tithonia diversifolia) pertumbuhan dan hasil kol bunga pada sistem pertanian organik. Skripsi. Fakultas Pertanian Universitas Bengkulu, Bengkulu.

Sinaga, P., Meirani dan Y. Hasanah. 2014. Respons pertumbuhan dan produksi kailan (Brassica oleraceae L.) pada pemberian berbagai dosis pupuk organik cair paitan (Tithonia diversifolia (Hemsl.) Gray). Jurnal Agroekoteknologi, 2(4): 1584 - 1588.

Sinartani. 2013. Inovasi teknologi penanganan limbah. Agroinovasi, Badan Litbang Pertanian.
Syafrudin, A., dan A. Wachid. 2015. Pengaruh pupuk organik cair dan pemotongan umbi bibit terhadap pertumbuhan dan produksi bawang merah Allium ascalonicum L.). Jurnal Agroekoteknologi, 12(1): 12-21.

Syofia, I., A. Munar dan M. Sofyan. 2014. Pengaruh pupuk organik cair terhadap pertumbuhan dan hasil dua varietas tanaman jagung manis (Zea mays saccharata Sturt). Jurnal Agrium, 18(3): 208-218.

Walid, F.L. dan Sosylowati. 2016 Pengaruh konsentrasi pupuk organik cair terhadap dan pertumbuhan hasil beberapa varietas tanaman kedelai (Glycine $\max$ L.). Jurnal Ziraa'ah, 41(1): 84-96.

Widiastutik, Y., H. Rianto dan Historiawati. 2018. Pengaruh komposisi dosis pupuk urea, SP-36, KCl, dan pupuk organik cair NASA terhadap hasil tanaman bawang merah (Alllium ascolanicum L.). Jurnal Ilmu Pertanian Tropika dan Subropika, 3(2):61-65.

Yetti, H. dan E. Elita. 2008. Penggunaan pupuk organik dan $\mathrm{KCl}$ pada tanaman bawang merah (Allium ascalonicum L.). Jurnal Sagu, 7(1): 13-18.

Yulianingsih, R. 2018. Pengaruh pupuk kandang kotoran ayam terhadap pertumbuhan dan hasil tomat (Lycopersicum esculentum, Mill). Piper, 26(14): 313-320.

Utami, R. L. 2018. Pertumbuhan vegetatif jeruk gerga pasca okulasi diberi pupuk organik cair pada kosentrasi yang berbeda. Skripsi. Fakultas Pertanian. Universitas Bengkulu, Bengkulu. 